\title{
Practical Challenges in Private Stewardship of Rangeland Ecosystems: Yellow Starthistle Control in Sierra Nevadan Foothills
}

\author{
Clare E. Aslan, ${ }^{1}$ Matthew B. Hufford, ${ }^{2}$ Rebecca S. Epanchin-Niell, ${ }^{3}$ Jeffrey D. Port, ${ }^{4}$ \\ Jason P. Sexton, ${ }^{2}$ and Timothy M. Waring ${ }^{5}$ \\ Authors are Doctoral Candidates, ${ }^{1}$ Department of Evolution and Ecology, ${ }^{2}$ Department of Plant Sciences, ${ }^{3}$ Department of Agricultural and Resource \\ Economics, ${ }^{4}$ Department of History, and ${ }^{5}$ Department of Environmental Science and Policy, University of California, Davis, CA 95616, USA.
}

\begin{abstract}
Private landowners are often de facto stewards of biodiversity and ecosystem services. In California's Sierra Nevada foothills, ranchers frequently present the only defense against biological invasions in private rangelands. Although ranchers' land management goals (e.g., the desire to control invasive species) can be consistent with ecosystem protection, practical constraints often limit their success. Considerable research on the invasive weed, yellow starthistle (Centaurea solstitialis L.), has produced numerous control strategies. Nevertheless, the range of this noxious weed continues to increase. We used surveys and interviews to document the weed control efforts of 202 ranchers and to identify practical limitations to their efficacy. Overall, $86 \%$ of ranchers who had experienced yellow starthistle infestation had attempted control, using one or more of 19 methods. Early response reduced negative effects from yellow starthistle. Control methods learned from agricultural advisors were reported more effective than those learned elsewhere. Limitations to yellow starthistle control in our study population resulted from incomplete information regarding control methods, complexity of weed control in heterogeneous landscapes, inconsistent application of methods, and lack of long-term planning for weed control. Such hindrances make it difficult for landowners to implement control methods promoted by researchers. This gap between science and practice contributes to the continued increase of yellow starthistle within the study region. To shrink this gap, researchers and agricultural advisors can incorporate environmental heterogeneity into applied agricultural research, use land stewards' knowledge and experience, and increase public education.
\end{abstract}

\section{Resumen}

Los dueños de tierras privadas son a menudo de facto guardianes de la biodiversidad y de los servicios del ecosistema. En las estribaciones de la Sierra Nevada de California, los ganaderos frecuentemente son la única defensa contra las invasiones biológicas en los pastizales privados. Si bien las metas de manejo de tierra de los ganaderos (por ejemplo, el deseo para controlar especies invasivas) pueden ser consistentes con la protección del ecosistema, las restricciones practicas a menudo limitan su éxito. La investigación amplia en la maleza invasiva, el abrepuño amarillo (Centaurea solstitialis L.) ha producido numerosas estrategias de control. Sin embargo, el rango de esta maleza nociva continúa en aumento. Nosotros utilizamos encuestas y entrevistas para documentar los esfuerzos de control de la maleza de 202 ganaderos y para identificar las limitaciones prácticas a su eficacia. En general el $86 \%$ de los ganaderos que habían experimentado la infección del abrepuño amarillo han intentado el control, usando uno o más de 19 métodos. La respuesta temprana redujo los impactos negativos del abrepuño amarillo. Los métodos de control aprendidos de los asesores agrícolas fueron reportados mucho más eficientes que esos aprendidos en otros lugares. Las limitaciones al control del abrepuño amarillo en nuestra población de estudio resultaron de: información incompleta recopilada de los métodos de control, complejidad del control de maleza en paisajes heterogéneos, la aplicación inconsistente de los métodos y la falta de planificación a largo plazo para el control de la maleza. Tales obstáculos hacen que sea difícil para los propietarios de tierras implementar los métodos de control promovidos por los investigadores. Esta brecha entre la ciencia y la práctica contribuye al continuo aumento del abrepuño amarillo dentro la región estudiada. Para reducir esta brecha, los investigadores y los asesores agrícolas pueden incorporar la heterogeneidad ambiental dentro la investigación agrícola aplicada, utilizando la experiencia y el conocimiento de los guardianes, e incrementar la educación pública.

Key Words: biological invasions, Centaurea solstitialis, heterogeneous landscapes, invasive species, landscape ecology, weed control

Authors M. B. H., R. S. E.-N., J. D. P., J. P. S., and T. M. W. contributed equally to this paper. Research was funded by the University of California, Davis, Biological Invasions Integrative Graduate Education and Research Traineeship (IGERT) grant NSFDGE 0114432 from the National Science Foundation.

The mention of a proprietary product does not constitute a guarantee or warranty of the product by the authors and does not imply its approval to the exclusion of other products that also may be suitable.

Correspondence: Clare E. Aslan, Dept of Evolution and Ecology, University of California, Davis, One Shields Ave, Davis CA 95616, USA. Email: ceaslan@ucdavis.edu

Manuscript received 30 October 2007; manuscript accepted 23 October 2008.

\section{INTRODUCTION}

Worldwide, private landowners manage large proportions of undeveloped landscapes and thus directly affect ecosystems and their services. Many effective technologies have been developed to address agroenvironmental challenges. Practical constraints to implementation, however, can create disparity between bestpractice recommendations of scientists and actual land management activities (Berry et al. 1998; Bradshaw and 
Borchers 2000; Acreman 2005). Such constraints include local, property-scale factors, such as financial and time constraints, landscape, and weather heterogeneity, and similar contextdependent factors (Berry et al. 1998; Bradshaw and Borchers 2000; Kaufman 2000; von Wiren-Lehr 2001; Didier and Brunson 2004).

Through interviews and surveys of cattle ranchers, we identified practical constraints hindering rancher response to the biological invasion of yellow starthistle (Centaurea solstitialis L.) in the Sierra Nevada foothills of California. As part of the California Floristic Province, the study area is a hotspot of biodiversity (Myers et al. 2000). Ranchers in this region are in large part the de facto guardians of ecosystem services (specifically food and fiber, fuel, water regulation, erosion control, cultural heritage, and aesthetic values; Standiford et al. 1996b; Brunson and Huntsinger 2008). By reducing ranch productivity, yellow starthistle threatens ecosystem services.

Native to Eurasia, yellow starthistle probably entered California in the 1850s (Gerlach 1997b) and became one of the most ecologically and economically damaging invasive plants in the state (DiTomaso et al. 2006). During the 1930s and 1940s, the weed spread with cattle-grazing through Sierra Nevada foothill rangelands (Gerlach 1997a; Sun 1997). The invaded area has doubled since 1985 (Maddox and Mayfield 1985) and approximately 14.3 million acres in California (roughly $15 \%$ of the state) are now infested (Pitcairn et al. 2006). Yellow starthistle decreases forage on rangelands, reduces wildlife habitat, displaces threatened plants, and depletes soil moisture (DiTomaso 2005). The economic harm caused by yellow starthistle from forage reduction and control efforts is greater than $\$ 17$ million annually in California and amounts to $6-7 \%$ of harvested pasture value for the entire state (DiTomaso 2005; Eagle et al. 2007).

Across the four counties of our study region, approximately 1.2 million acres of land ( $35 \%$ of total land area) are consistently managed for cattle production (US Department of Agriculture-National Agricultural Statistics Service [USDANASS] 2005). Despite long-standing cultural importance in the region, ranching has declined in the foothills over the past $40 \mathrm{yr}$ (Standiford et al. 1996b; Smethurst 1999; Walker and Fortmann 2003). Escalating regional land prices and property taxes (Standiford et al. 1996b; Walker and Fortmann 2003) prompt conversion of rangelands to housing developments, ranchettes, and intensive agricultural operations, such as vineyards (Standiford et al. 1996a; Liffmann et al. 2000; Giusti et al. 2004).

A network of local advisors, including county Agricultural Commission, University of California Cooperative Extension, and Natural Resources Conservation Service, provides advice and information for foothill ranchers who contend with yellow starthistle. Weed Management Areas (WMAs) coordinate invasive plant control efforts in each county. Although WMAs are loose organizations of many entities, lacking enforcement power, and are, therefore, perhaps weaker than single-entity agency bodies (Hershdorfer et al. 2007), they can streamline disparate efforts, educate the public, and coordinate volunteers. Moreover, yellow starthistle control information is readily available (e.g., DiTomaso et al. 2006; DiTomaso 2008). These resources propose a wide range of control techniques that have
Table 1. Population representation of both surveys and interviews.

\begin{tabular}{lcccc}
\hline County & $\begin{array}{c}\text { Census, }{ }^{1} \\
\text { No. }\end{array}$ & $\begin{array}{c}\text { Surveys, } \\
\text { No. (\%) }\end{array}$ & $\begin{array}{c}\text { Interviews, } \\
\text { No. }(\%)\end{array}$ & $\begin{array}{c}\text { Both, } \\
\text { No. }(\%)\end{array}$ \\
\hline Amador & 176 & $38(21.6)$ & $12(6.8)$ & $50(28.4)$ \\
Calaveras & 270 & $56(20.7)$ & $11(4.1)$ & $67(24.8)$ \\
Mariposa & 182 & $27(14.8)$ & $7(3.8)$ & $34(18.7)$ \\
Tuolumne & 187 & $41(21.9)$ & $10(5.4)$ & $51(27.3)$ \\
Total & 815 & $162(19.9)$ & $40(4.9)$ & $202(24.8)$ \\
\hline
\end{tabular}

${ }^{1}$ Number of farms with heifers and cows that gave birth in 2002. Source: US Census Bureau.

reduced yellow starthistle populations on test plots. They also recommend that ranchers use multiple methods in combination and adopt strategic, multiyear plans developed with advisor assistance and tailored to the ranch's own long-term control needs (DiTomaso et al. 2006).

Given this research and information network, why does yellow starthistle continue to spread in the Sierra Nevada foothills? Is there a disconnect between scientific recommendations and the on-the-ground realities experienced by ranchers? In this exploratory study, we administered surveys and interviews to ranchers to identify practical factors influencing the efficacy of their control efforts. Social science research methods permitted us to explore the effect that a specific economic and cultural way of life (ranching) has on an ecological problem. Insights unattainable through traditional ecological research can be gained from such merging of disciplines (Ludwig et al. 2001).

\section{METHODS}

We used a combination of surveys and interviews because both methods offer advantages. Surveys reached a large proportion of the ranchers in our study region with short-answer questions about infestation levels, attempted control techniques, common constraints, and ranch demographics. Interviews were time consuming (2-4 h apiece) but permitted us to explore the full yellow starthistle story on each ranch.

Surveys and interviews were administered to ranchers in Amador, Calaveras, Tuolumne, and Mariposa, California, counties, which form a continuous segment of the western slope of the Sierra Nevada. Ranchers in the study region were identified from the list of brands published as the Brand Book by the California Department of Food and Agriculture (CDFA) Bureau of Livestock Identification (CDFA 2006). This source lists all individuals with registered livestock brands and is the most comprehensive available database of area ranchers. However, it lacks recent information about ranches that have ceased to exist and does not distinguish between cattle ranchers and those managing other livestock. The Brand Book (CDFA 2006) population is thus larger than the total applicable population for this study. For this reason, we excluded some returned surveys from analysis (described below) and used the US Census Bureau's count of area cattle ranches to calculate the percentage of total area ranches sampled (Table 1; US Census Bureau 2002).

Our goal was to maximize the management area under the purview of sampled ranchers $(275000$ acres sampled in this study). Geographically, therefore, the proportion of the 
ranching landscape sampled was expanded through intentional oversampling of larger ranches for interviews, as described below.

\section{Surveys}

In February 2006, surveys were mailed to all noninterviewed study-area individuals with registered brands. In total, 875 surveys were sent; 25 were returned by the postal service as undeliverable, and 185 surveys were completed and returned by respondents. Because of seasonal changes and associated time constraints for ranchers, we did not conduct follow-up mailings as recommended by Dillman (2007). For this reason and because of the potential of respondent bias, results presented here should be considered exploratory and not be extrapolated beyond our sampled population. Twenty-three returned surveys were excluded from analyses because the respondents had no cattle $(n=18)$, had been interviewed $(n=2)$, or ranched entirely outside the study region $(n=3)$.

\section{Interviews}

In all, 40 interviews were completed. We called randomly sampled (CDFA 2006) ranchers to request interviews until eight interviews per county had been scheduled. We then selectively called ranchers in Amador, Calaveras, and Tuolumne, California, counties who manage large ranches (100 or more head of cattle) because such big ranches, although rare in the study area $(13.8 \%$ of all area ranches; US Census Bureau 2002), control a large proportion of the land invaded by yellow starthistle. Lists of "large ranchers" were obtained from a pastureland database for Amador and Calaveras counties and from a Cattlemen's Association representative for Tuolumne County. No such list was available for Mariposa County. Up to four ranchers were randomly chosen from each of these lists.

We called 104 Brand Book (CDFA 2006) individuals to request interviews and made contact with $68 \%(n=71)$. Thirty-seven percent $(n=26)$ of these were not applicable to our study, whereas $49 \%(n=35)$ agreed to interviews. Inapplicable individuals had no cattle $(n=18)$, had moved out of the study region $(n=3)$, were deceased $(n=4)$, or were closely related to one of the researchers $(n=1)$. Ranchers who declined interviews $(n=10)$ did so because of illness, lack of time, lack of interest, or distrust of nonranchers. Four willing individuals were not interviewed because of scheduling constraints. In total, seven random interviews in Mariposa County and eight from each of the other counties were completed. Of the 14 large ranchers called, 11 (79\%) agreed to interviews. Two of those $(2 / 11 ; 18 \%)$ were not interviewed because of scheduling conflicts. The three $(3 / 14 ; 21 \%)$ that declined cited lack of time. Four, three, and two large ranchers were interviewed from Amador, Calaveras, and Tuolumne, California, counties, respectively.

Each author conducted six to eight interviews between 3 February 2006 and 5 May 2006. Three to five different authors administered the interviews in each county. Authors received training on interview methods during a formal course at the University of California, Davis, on interdisciplinary approaches to biological invasion research. To minimize differences in information gathering between interviewers, we used structured interviews and a comprehensive note-taking template that included the exact wording of all questions as well as blank tables to guide recording. During interviews, all notes were taken directly onto this template. Interviews were digitally recorded and later transcribed unless the interviewee objected. In all, four interviewees objected to the digital recording, but because the note-taking template was used for all interviews, and the same structure carefully followed, those interviews provided the full complement of numerical data for later analysis. We therefore analyze all interviews together in our "Results" section.

Comparing the number of ranchers participating in this study to the US Census Bureau's estimate of the population of cattle ranchers in the study region, we sampled $24.8 \%$ of all applicable ranches (defined by the US Census Bureau as farms that had heifers or cows that gave birth in 2002) in the study region. Broken down by method, $4.9 \%$ of study area ranchers were interviewed, and $19.9 \%$ were surveyed (Table 1).

Because interviews and surveys reflect slightly different subsets of ranchers (large ranches were overrepresented in the former) and because differences in the methods may have influenced responses, we distinguish their results below. All statistical tests were performed using the JMP 5.0.1.2 statistical package. The Bonferroni correction for multiple comparisons was used when appropriate (Hochberg 1988).

\section{RESULTS}

Surveyed ranchers ranged in age from 22 to 93, with a mean age of 58 . Ranching was the primary income source for $21 \%$ of respondents and the primary occupation for $31 \%$. Sixty-seven percent of ranchers surveyed had $20 \mathrm{yr}$ or more of ranching experience.

\section{Extent of Yellow Starthistle Infestation}

Fully $93 \%$ of survey respondents have had yellow starthistle on their ranch. As expected because of the known spread pattern of yellow starthistle from north to south across California (Maddox and Mayfield 1985), infestation levels (proportion of rangeland infested) were higher among respondents in the two northern counties (Amador and Calaveras) than in the southern counties (Tuolumne and Mariposa; paired Student's $t$ tests; $P<0.05)$. From the survey, the mean percentages of unimproved pasture infested with yellow starthistle in the northern counties $(18.1 \%, 21.1 \%)$ were over twice that of the southern counties $(7.3 \%, 3.6 \%)$.

\section{Motivations for Control}

Sampled ranchers are concerned about the future of ranching. During interviews, $68 \%$ of subjects mentioned land conversion (development, subdivision, etc.) as a pressure on ranching. Yellow starthistle has added to the economic hardship of ranchers. Discussing control motivation, $58 \%$ of interviewees cited the need to protect forage. Indeed, $40 \%$ of interviewed ranchers perceived that a yellow starthistle infestation could become grave enough to endanger a ranch's operation because of forage reduction. Among surveyed ranchers, respondents that reported economic impacts from yellow starthistle beyond the costs of control (such as maintaining fewer cattle, leasing more land, reduced cattle weight gain, and buying more hay) 
Table 2. Chemical treatment, manual removal, and grazing represent the majority of applied yellow starthistle control methods.

\begin{tabular}{lccccc}
\hline \multirow{2}{*}{ Method } & \multicolumn{2}{c}{ Survey } & & \multicolumn{2}{c}{ Interview } \\
\cline { 2 - 3 } \cline { 5 - 6 } \cline { 5 - 6 } Manual removal & Ranchers, No. & $\%$ & & Ranchers, No. & $\%$ \\
Chemical (unspecified) & 46 & 25.3 & & 14 & 13.5 \\
Transline & 49 & 26.9 & & 10 & 9.6 \\
Grazing & 23 & 12.6 & & 11 & 10.6 \\
Roundup & 19 & 10.4 & & 14 & 12.4 \\
Mowing & 16 & 8.8 & & 16 & 15.4 \\
Burning & 14 & 7.7 & & 12 & 11.5 \\
Cultivation & 8 & 4.4 & & 10 & 9.6 \\
Mechanical (other) & 4 & 2.2 & & 5 & 4.8 \\
Biocontrol & 1 & 0.5 & & 2 & 1.9 \\
Revegetation & 1 & 0.5 & & 6 & 5.8 \\
Irrigation & 1 & 0.5 & & 2 & 1.9 \\
Total & & & & \\
\hline
\end{tabular}

also tended to have higher yellow starthistle infestation levels (logistic regression, $P<0.0001$ ). Alternatively, $13 \%$ of interviewees identified only aesthetic reasons and strong dislike of yellow starthistle as spurring their control efforts.

\section{Response Time}

Overall, ranchers averaged a lag time of $6 \mathrm{yr}$ to respond to yellow starthistle after it appeared on their land. Response time separates ranchers into three distinct groups. Of the 38 ranchers interviewed who had yellow starthistle, 12 began controlling it immediately (Early Responders), 20 waited at least $5 \mathrm{yr}$ before responding to the invasion (Late Responders), and 6 began control immediately upon commencing ranch operations on land already infested (Late Arrival). Late Responders averaged $11 \mathrm{yr}$ before commencing control efforts. Of the 12 Early Responders, only one reported ongoing problems from yellow starthistle. Among both Late Responders and Late Arrivals, however, 50\% had ongoing and notable problems from yellow starthistle.

\section{Control Implementation}

Participants in both the survey and interview most commonly used the same six control methods: manual removal, Roundup herbicide application, Transline herbicide application, mowing, grazing, and burning (Table 2). In all, sampled ranchers used 19 methods. For 16 of these methods, ranchers described advantages and disadvantages (Table 3). Additionally, survey respondents rarely reported use of the herbicides 2,4,5-T, Garlon 4, and unspecified defoliant, but no detailed information regarding these methods was provided.

Among surveyed ranchers, 25 (15\%) had starthistle but made no control effort. These ranchers were more likely to trust local information sources (neighbors, family, and friends; Pearson's $\chi^{2}$ test; $P=0.0328$ ) and to claim that inadequate information limited control (Pearson's $\chi^{2}$ test; $P=0.0072$ ) than were other ranchers. Among interviewees, $5(13 \%)$ with yellow starthistle chose not to control it. Two of these had infestations too small to concern them; two cited prohibitive control cost; and the fifth blamed lack of time and lack of effective control measures.
Overall, $86 \%$ of sampled ranchers reporting any history of yellow starthistle on their ranch had attempted to control the infestation. Unlike the survey, the interview explored the diversity and order of control methods attempted by each rancher; $33(83 \%)$ interviewees had attempted at least one method of control. Of these, $28(85 \%)$ had tried two or more methods with $12(36 \%)$ using four or more methods.

Interviewed ranchers described their yellow starthistle control efforts in detail, enabling us to assess which individuals created a strategic, long-term management plan instead of practicing short-term, reactive control. Only five interviewed ranchers had developed strategic plans. Most ranchers were reactive, selecting methods based on immediate, short-term conditions, and we thus term them ad hoc controllers. Of these, $57 \%$ can be called satisficers, after Simon (1959), whereas we label the remainder inconsistent controllers. Satisficers test different strategies and then settle on one or two that provide good enough control. They then repeat these methods without further assessment. Inconsistent controllers, on the other hand, exert minimal effort for specific short-term outcomes (such as aesthetic weed control near a home) or use a rapidly shifting set of control measures. Many inconsistent controllers choose arbitrarily from a suite of control techniques each year. One such rancher, in a decade, tried mowing, spraying with 2,4-D, flood irrigation, Roundup, Transline, discing, and burning.

Because of seed-bank dynamics, the number of years over which methods are used is important. Among both surveyed and interviewed ranchers, manual removal was used for relatively long lengths of time $(\sim 10 \mathrm{yr})$, and Transline for short time spans ( $\sim 3 \mathrm{yr}$; Table 4$)$.

\section{Overall Control Success}

We used multivariate linear regression to examine the role of control efforts among survey respondents in predicting the spread of yellow starthistle on unimproved rangeland. Infestation levels for the year 2005 (unimproved pasture acres reported as infested by survey respondents) were predicted based on reported, year 2000 infestation levels and whether or not ranchers had attempted control. Infestation levels were square-root-transformed to meet homoscedasticity assumptions and because constant radial growth of a spreading invasion means that the square root of invaded areas should increase linearly (Hastings 1996). The area of unimproved pastureland that was infested in 2005 was highly positively correlated with infestation levels in $2000(P<0.0001)$ and negatively correlated with sampled ranchers' control effort $(P=0.029$; Table 5).

Ranchers blamed a number of factors for reducing their control capacity. Of survey respondents, $46 \%$ and $38 \%$ identified lack of money and lack of time, respectively, as limits to their control ability. Lack of effective control measures was implicated by $20 \%$, whereas lack of information was selected by $8 \%$ of respondents.

The interview format enabled us to identify an additional constraint reported by a considerable number $(40 \%)$ of ranchers: heterogeneity of landscape. Interviewees reported that mowing, cultivation, and discing are impossible, and aerial Transline application difficult, where land is broken, rocky, steep, or heavily forested (Table 3). 


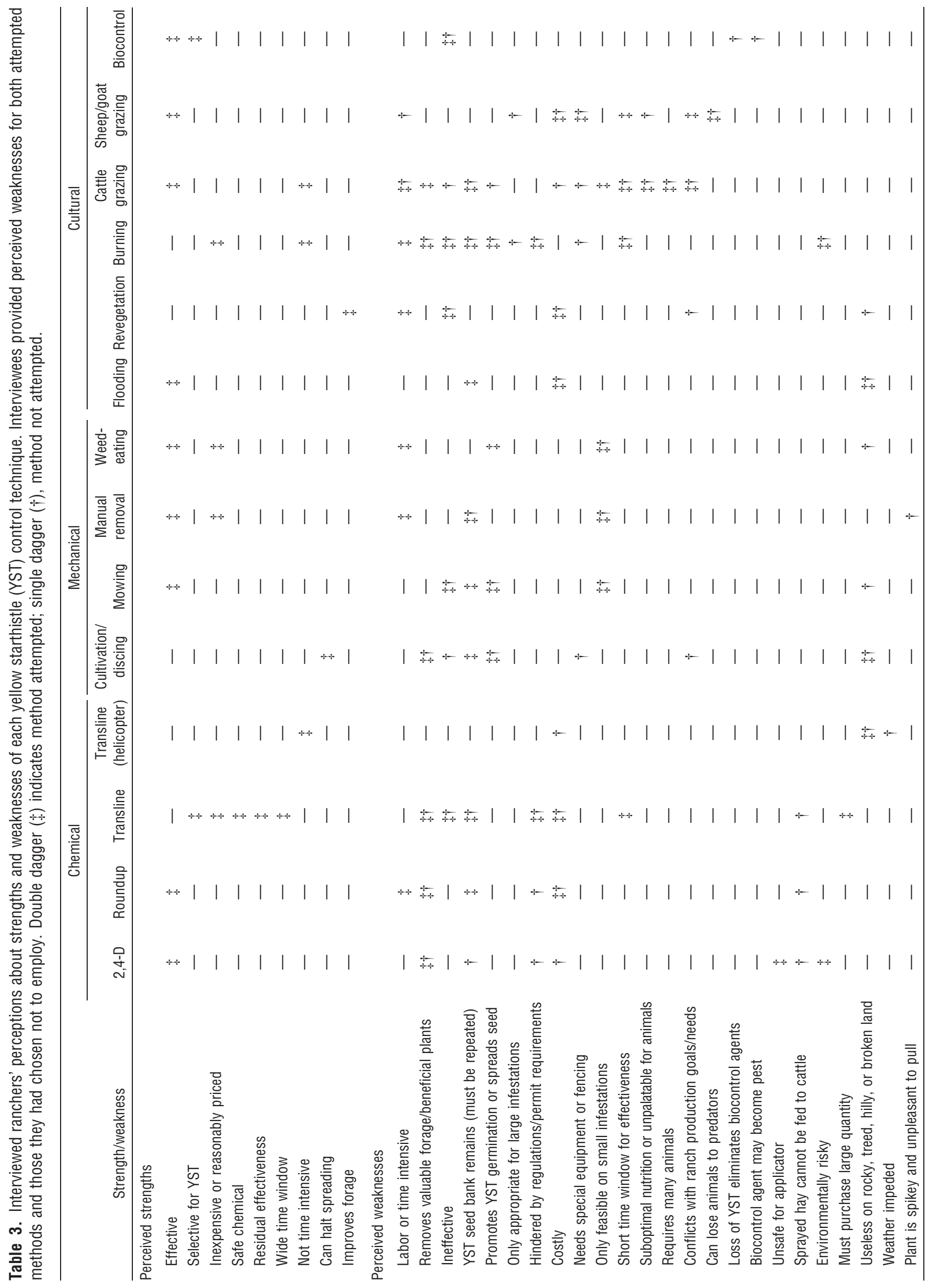


Table 4. Average consecutive number of years (Years of use) that interviewees applied each control method. Values are based on reports by the subset $(n)$ of interviewees (overall $N=40$ ) that had attempted each method.

\begin{tabular}{lcc}
\hline \multicolumn{1}{c}{ Method } & $n$ & Years of use \\
\hline Manual removal & 14 & 10.3 \\
Roundup & 16 & 10.2 \\
Mowing & 12 & 8.5 \\
Cattle grazing & 10 & 7.9 \\
Chemical (unspecified) & 10 & 7.4 \\
Mechanical (general) & 2 & 6.5 \\
Graze (noncattle) & 4 & 6.3 \\
Cultivation & 5 & 4.2 \\
Flooding & 2 & 3.3 \\
Burn & 10 & 2.6 \\
Transline & 11 & 2.5 \\
Biocontrol & 6 & 1.7 \\
Revegetation & 2 & 1 \\
\hline
\end{tabular}

\section{Efficacy of Specific Control Methods}

Survey respondents rated the efficacy of each control method they had applied, and interviewees provided detailed explanations of method strengths and weaknesses (Table 3). We examined rated efficacy from surveys of the most common control strategies (Transline, manual removal, grazing, Roundup, mowing, and burning; Fig. 1). Transline and manual removal were most frequently given high efficacy ratings. Mowing and burning were most commonly considered low efficacy, whereas grazing and Roundup were intermediately effective. These results were supported qualitatively in interviews. Many interviewees felt that Transline was the best available method. Selectivity for a few plant families was cited as a strength of Transline, as was low safety risk for applicators. The main drawbacks to Transline included expense, inadequate coverage during aerial spraying of broken terrain, and damage to clover (Trifolium L. spp.) forage. Many interviewees reported success in manual removal of small infestations early in the season (before flowering). The amount of time required and, therefore, the limited application area was identified during interviews as a constraint to this method.

Mowing and burning were identified in surveys as the leasteffective methods, a result strongly supported by interviews. No interviewed ranchers were satisfied with mowing as a control strategy. Ranchers explained that mowing does not prevent seed set and may spread seed beyond initial populations. Likewise, none of the interviewees were satisfied with burning. Although burning has some advantages (low expense and low time commitment), interviewees complained that burning damages beneficial forage without killing starthistle seed. Several ranchers reported substantial spread of yellow starthistle following a burn. Furthermore, they noted the high risks associated with fire.

Interviewees identified practical considerations that hinder the use of other control methods, as well. Goat grazing, for example, though considered highly effective by some interviewees, was criticized by others because goats are vulnerable to predators and require improved fencing. Other limitations on control methods included weather dependence, slim time
Table 5. Effect of rancher control efforts on year $2005^{1}$ yellow starthistle (YST) infestation levels (acres). Both infestation levels (acres) in $2000^{1}$ and whether or not control was attempted significantly affect the amount of spread of YST between 2000 and $2005\left(R^{2}=0.952 ; N=81\right)$. Surveys with missing data were excluded from this analysis.

\begin{tabular}{lrrrc}
\hline \multicolumn{1}{c}{ Term } & Estimate & \multicolumn{1}{c}{ SE } & $t$ ratio & Probability $>|t|$ \\
\hline Intercept & 18.171 & 10.594 & 1.72 & 0.0903 \\
Control not applied & -24.532 & 11.041 & -2.22 & 0.0292 \\
YST level (2000) & 1.109 & 0.028 & 39.28 & $<0.001$ \\
\hline
\end{tabular}

Data were square-root-transformed.

windows of applicability, and nontarget effects. Strengths and weaknesses of all methods discussed in the interviews are presented here (Table 3). Notably, direct contradictions exist, reflecting the importance of individual experience.

\section{Information Sources}

Survey respondents reported the source of information for each control technique that they had applied. We grouped these sources into four categories and examined the relationship between the source of information and the reported efficacy of the method. The source categories were Advisors, Personal Experience, Media/ Commercial (e.g., magazines and feed shops), and Local Individuals (including other ranchers, neighbors, family, and friends). Advisors and Local Individuals were the primary sources of control techniques used by ranchers and were the only categories with sufficient observations to permit statistical examination. Contingency analysis revealed that methods learned from Advisors were generally rated more effective than those learned from local sources $(P<0.01$; Table 6$)$. Transline, which was given the highest efficacy ratings of all the control methods reported in our study, was recommended to ranchers by Advisors (16 reports) more frequently than by all other information sources combined (5 reports).

\section{DISCUSSION}

Interaction between ecology and the social sciences to elucidate the relationship between human motivations and decisions is key to sustainable management of common resources (Folke 2007). Here, surveys and interviews revealed that participant cattle ranchers rarely develop long-term strategic plans for management of yellow starthistle. Weed control practice among these ranchers, therefore, fails to follow scientific management recommendations. Practical constraints contributing to this disparity include poor understanding among ranchers of control methods and weed dynamics, heterogeneous landscapes that are incompatible with many available control methods, and shortfalls of time and money resulting in lack of consistent investment in weed control.

\section{Practical Constraint 1: Poor Understanding of Control Methods and Weed Dynamics}

No single control prescription worked for all ranches across the study. The diversity of available tools, each with strengths and weaknesses, makes adequate control choice and application 


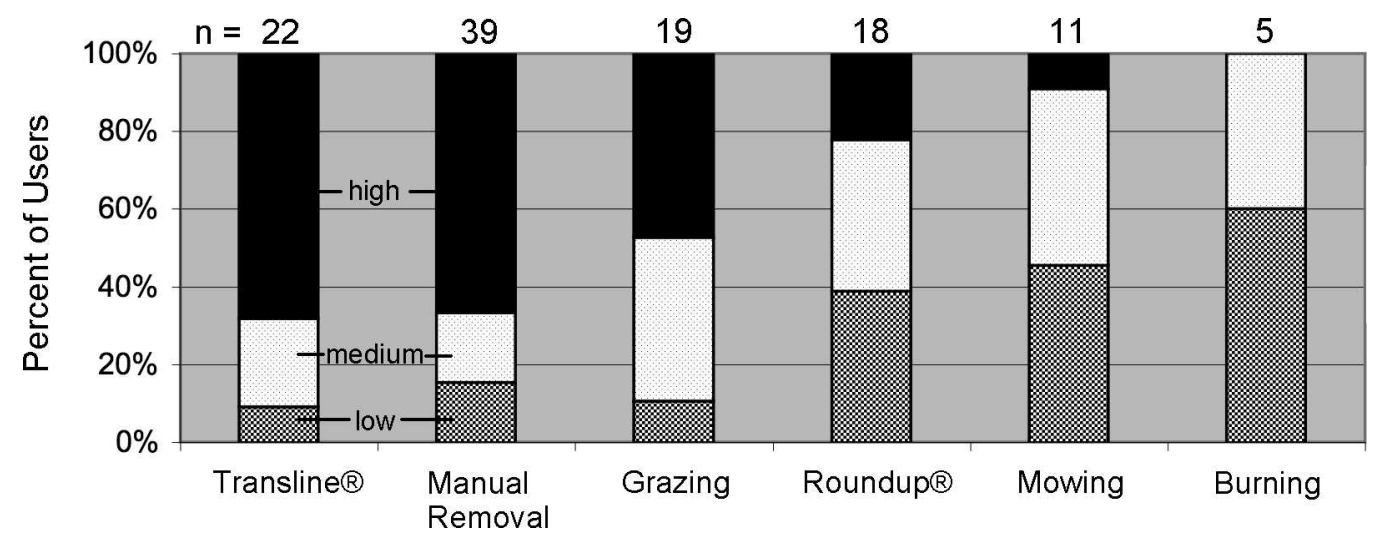

Figure 1. Surveyed ranchers who had attempted each of the most common control techniques rated their effectiveness as low, medium, or high. Transline and manual removal were most commonly rated highly effective, whereas mowing and burning were more often given a low-effectiveness rating.

challenging. Methods are also dependent on scale, as illustrated by Transline, which is cost effective only in large applications, and by manual removal, which is time effective only on small infestations. Perceptions of appropriate method-application conditions and techniques varied and were sometimes contradictory. Interviews also revealed limited understanding of seedbank dynamics. Many interviewees described control efforts limited to a year or two that were halted when yellow starthistle populations had visibly decreased. Because total eradication from an area cannot be achieved so quickly, these breaks in control allow seed-bank recharge and future recurrence of the weed.

Elsewhere, ranchers have been shown to prefer straightforward, low-cost, easy-to-implement management practices and to avoid methods that they feel are incompatible with ranch productivity (Rowan et al. 1994; Coppock and Birkenfeld 1999; Kreuter et al. 2001). Complexity of some weed control methods (e.g., grazing) or concern that they will impact ranch production (e.g., revegetation) may, therefore, keep ranchers from using them correctly (Huntsinger et al. 2007). Improved weed education would facilitate use of these methods.

\section{Practical Constraint 2: Heterogeneous Landscapes}

Interviewees considered many control techniques recommended in yellow starthistle management literature to be unfeasible because of specific terrain, climate, and other local considerations. Hence, it is difficult to match methods to circumstance, and appropriate selection or adaptation of control methods is

Table 6. Contingency table of sources of yellow starthistle control information and the effectiveness ratings applied to the corresponding methods by surveyed ranchers. Control methods learned from advisors (e.g., university extension agents or County Agricultural Commissioners) received significantly higher effectiveness ratings than did methods learned from local sources (including other ranchers, neighbors, family, and friends).

\begin{tabular}{lcccc}
\hline & \multicolumn{3}{c}{ Effectiveness } & \\
\cline { 2 - 4 } Information source & Low & Medium & High & Total \\
\hline Advisors & 6 & 12 & 24 & 42 \\
Local individuals & 10 & 8 & 5 & 23 \\
\hline
\end{tabular}

constrained. This practical limitation to the control of yellow starthistle could stem from a failure to incorporate landscape heterogeneity as a variable in many field trials of weed control strategies (D'Antonio et al. 2004). Generalized control recommendations resulting from field trials in homogeneous landscapes can be frustrating for private land managers, when implementation appears impossible in more specific and variable conditions.

\section{Practical Constraint 3: Lack of Time and Money to Invest in Weed Control}

Strategic management plans require monitoring (Sheley 1995), which requires time and money investments (Lee 1999). Because lack of money and lack of time were major factors impeding many ranchers' ability to control yellow starthistle, strategic plan development may be challenging. Only a few interviewees use a strategic management plan structured around long-term objectives. The remainder responds reactively, working to lessen short-term impacts rather than taking a proactive approach to reduce or eradicate the invasion. Ad hoc response tends to be inconsistent and lag behind the invasion. Even effective methods were usually employed for short durations (Table 4). This trend supports findings that ranchers are likely to underinvest in yellow starthistle mitigation because benefits may not be realized for long periods (Eagle et al. 2007); they tend to find short-term benefits and effects more persuasive than long-term advantages when deciding whether and how to control infestations (Kreuter et al. 2001).

Illustrating the cost of control lags, sampled ranchers who responded early to yellow starthistle enjoyed reduced negative impacts. Early Responders apparently capitalize on accrued management benefits. Delaying control results in both greater land areas incurring weed damage and larger sources of future spread. Other studies have shown that weed control early in an invasion reduces total control cost, the damages incurred, and the propagule pressure for new infestations (Smith et al. 1999; Higgins et al. 2000; Rejmánek and Pitcairn 2002; Taylor and Hastings 2004). The cost of lack of control is exacerbated by seed-bank dynamics in this system because the seed bank is long lasting (3-8 yr) and is renewed each year that control is delayed or suspended. 


\section{Additional Yellow Starthistle Control Considerations}

Although this article is restricted to property-scale, practical hindrances to control, regional-scale dynamics in our study system further complicate response to yellow starthistle. Our surveys and interviews elucidated a strong lack of coordination between neighboring landholders, with consequent yellow starthistle spread across jurisdictional boundaries and a high risk of reinfestation even after successful control.

In addition to the yellow starthistle control methods that have been attempted in the past and are thus examined in this study, new techniques are becoming available to private landowners. Milestone, a new herbicide with the same level of specificity as Transline, appears effective at lower application rates, making it a cheaper alternative (J. DiTomaso, personal communication, April 2007). Current and promising research into nonchemical methods of yellow starthistle control is also underway. Such work explores both biological control (e.g., Gutierrez et al. 2005) and the role of native and biodiverse species communities in rangeland health and resistance to invasion (e.g., Zavaleta and Hulvey 2004; Morghan and Rice 2005; Huntsinger et al. 2007). To be successful, however, ecological approaches require private landowner education in underlying scientific principles. Researchers developing these methods must also consider landscape heterogeneity as well as costs to landowners.

\section{Recommendations}

Although this study was exploratory, it supports five concrete recommendations applicable to sampled ranchers and the research/agricultural advisor system. First, when weed-caused damages are significant and continual reinfestation is uncertain, we suggest that ranchers respond rapidly to new weed infestations. Sampled ranchers who responded early to yellow starthistle reported reduced negative impacts from the weed. Small infestations can be confronted with inexpensive, effective methods, such as manual removal. The economic benefit-cost ratio of rapid response, however, declines when reinfestation from neighboring lands is a likely ongoing occurrence. Under such circumstances, coordination with neighbors becomes necessary for cost-effective control.

Second, we recommend to research scientists that they access knowledge held by agricultural communities. Ranchers in this study provided feedback about conditions conducive to particular methods (Table 3). The value of such local experience has been noted in other resource management scenarios (Berkes et al. 2000; Moller et al. 2004; Folke et al. 2005). Indigenous knowledge can form a source of knowledge and experimentation for an adaptive management system (Agrawal 1995).

Our remaining three recommendations are interrelated. The on-the-ground control experience of these participants indicates a need for yellow starthistle control experiments to consider landscape heterogeneity. Our third recommendation is, therefore, that weed research scientists incorporate topographical, ecological, and meteorological variation while studying control techniques. Specifically, field trials should be conducted in multiple locations that span the landscape diversity commonly encountered by private land managers. For example, trials could be conducted in collaboration with ranchers on a set of ranches chosen to reflect variation in landscape features. Results from these trials, including conditions resulting in control failure, should be publicized to extension agents, so that method performance under specific conditions becomes common knowledge.

Following from this, our fourth recommendation is that rancher education be increased in the study region. The ranchers we interviewed demonstrated incomplete knowledge of control techniques (when, where, and for how long to administer treatments), the value of long-term management plans, and the role of the seed bank. We recommend that education in these areas primarily comprise direct interaction (teaching environments, such as workshops), which has been shown more effective than brochures in rural land management situations (Toman et al. 2006). Education can be provided by Weed Management Areas, university extensionists, and the state Department of Food and Agriculture. These resources already offer trainings on various subjects, but funding limits these offerings and rancher time constraints restrict their attendance.

Our fifth recommendation addresses these time and funding problems: governmental agencies should renew cost-share assistance and do so with integral education components. In this study, ranchers attempting any control tended to have lower spread rates and, therefore, provided a public service. However, monetary constraints were cited as a major factor impeding control. California's land prices are among the highest in the nation, but ranching itself is barely profitable, driving many ranchers to additional forms of income. The opportunity cost to remain in ranching is enormous. Ongoing weed control that may cost thousands of dollars annually further increases the risk that ranchers will sell to developers. Other studies show that management with high cost, relative to its immediate economic benefit, is unlikely to be carried out, particularly by ranchers with small properties or alternative sources of income (Rowan and White 1994); it simply becomes cost prohibitive, regardless of the broader benefit to society (Kreuter et al. 2004). Many of our participant ranchers have participated in past weed control cost-share programs. However, governmental investment in cost-share and other assistance has been spotty in the recent past because of California's large budget deficit. Because ranchers are most likely to invest in starthistle control while infestation is highest, we recommend a cost-share setup that disperses its greatest assistance later (third year and after) in the treatment program, so as to achieve longer-term seed bank reduction. Furthermore, we suggest that financial assistance be contingent upon ranchers participating in associated educational workshops addressing the information gaps identified in this study.

\section{IMPLICATIONS}

The percentage of rangeland infested with yellow starthistle increased between 2000 (14\% overall) and 2005 (16\% overall) across study ranches. Meanwhile, ranching is dwindling in the region. From 1997 to 2002, the number of farms with beef cows decreased by $15.3 \%$ in the study area (USDA-NASS 2002). Weeds reduce productivity on ranches already under economic pressure, and our data suggest that this motivates ranchers to invest in control. If infestations continue to rise, the profitability and survival of existing ranches will be doubtful. 
As stewards of open space, sampled ranchers make substantial efforts to control biological invasions when their livelihoods are at stake. Control effectiveness relies upon both information access and availability of control methods flexible enough to overcome practical barriers. Should ranchers fail to maintain productive land, the relatively stable provisioning of ecosystem services from these regions are at risk (Brunson and Huntsinger 2008). In California, ranch failure will augment landscape fragmentation and conversion to subdivisions, ranchettes, and vineyards in the Sierra Nevada foothills. Opportunities to bolster private-land stewardship of ecosystem services through research, education, and financial assistance should, therefore, be sought and cultivated wherever possible.

\section{ACKNOWLEDGMENTS}

We thank Sharon Strauss, Carole Hom, Steve Schoenig, Mark Lubell, Joe DiTomaso, Brendon Larson, Kari Norgaard, and Kevin Rice for advice throughout this project. Guidance in methodology and analysis from Mark Grote, Mark Lubell, Kari Norgaard, and Neil Willits was highly beneficial. This manuscript was improved by comments and feedback from Mark Lubell, Joe DiTomaso, Carla D’Antonio, F. Stuart Chapin, Mark Brunson, Mark Eiswerth, Marcel Rejmánek, Erika Zavaleta, and three anonymous reviewers. Additional study system insights were provided by Scott Oneto, Dan Port, Scott Stone, Wendy West, Bill Frost, Marian Chambers, Roger S. Ingram, Kenneth Churches, Mary Mutz, Karl Kerstan, Mike Boitano, and Jay Norton. Thanks also to the California Cattlemen's Association for endorsing this project and offering assistance. We are indebted to the ranchers of this study for their generosity, hospitality, and honesty.

\section{LITERATURE CITED}

ACREMAN, M. 2005. Linking science and decision-making: features and experience from environmental river flow setting. Environmental Modelling \& Software 20:99-109.

Agrawal, A. 1995. Indigenous and scientific knowledge: some critical comments. Indigenous Knowledge and Development Monitor 3:3-6.

Berkes, F., J. Colding, and C. Folke. 2000. Rediscovery of traditional knowledge as adaptive management. Ecological Applications 10:1251-1262.

Berry, J., G. D. Brewer, J. C. Gordon, and D. R. Patton. 1998. Closing the gap between ecosystem management and ecosystem research. Policy Sciences 31:55-80.

Bradshaw, G. A., and J. G. Borchers. 2000. Uncertainty as information: narrowing the science-policy gap. Conservation Ecology 4:7.

Brunson, M. W., AND L. Huntsinger. 2008. Ranching as a conservation strategy: can old ranchers save the new West? Rangeland Ecology \& Management 61:137-147.

[CDFA] California Department of Food and Agriculture. 2006. California brand book. Available at: http://www.cdfa.ca.gov/ahfss. Accessed 16 April 2008.

Coppock, D. L., AND A. H. BiRKENFELD. 1999. Use of livestock and range management practices in Utah. Journal of Range Management 52:7-18.

D’Antonio, C. M., N. E. Jackson, C. C. Horvitz, and R. Hedberg. 2004. Invasive plants in wildland ecosystems: merging the study of invasion processes with management needs. Frontiers in Ecology and the Environment 2:513-521.

Didier, E. A., And M. W. Brunson. 2004. Adoption of range management innovations by Utah ranchers. Journal of Range Management 57:330-336.

Dillman, D. A. 2007. Mail and internet surveys: the tailored design method-2007 update with new internet, visual, and mixed-mode guide. Hoboken, NJ, USA: John Wiley and Sons. $523 p$.

DiTomaso, J. M. 2005. Yellow starthistle. In: C. L. Duncan and J. K. Clark [eds.]. Lawrence, KS, USA: Weed Science Society of America.
DiTomaso, J. M. 2008. Yellow starthistle information. Available at: http://wric. ucdavis.edu. Accessed 16 April 2008.

DiTomaso, J. M., G. B. Kyser, and M. J. Pitcairn. 2006. Yellow starthistle management guide. Berkeley, CA, USA: California Invasive Plant Council. Publication 2006-03. $74 \mathrm{p}$.

Eagle, A. J., M. E. Eiswerth, W. S. Johnson, S. E. Schoenig, and G. C. van Kooten. 2007. Costs and losses imposed on California ranchers by yellow starthistle. Rangeland Ecology \& Management 60:369-377.

FoLKE, C. 2007. Social-ecological systems and adaptive governance of the commons. Ecological Research 22:14-15.

Folke, C., T. Hahn, P. Olsson, and J. Norberg. 2005. Adaptive governance of socialecological systems. Annual Review of Environmental Resources 30:441-473.

Gerlach, J. D., JR. 1997a. How the West was lost: reconstructing the invasion dynamics of yellow starthistle and other plant invaders of western rangelands and natural areas. Proceedings of the California Exotic Pest Plant Council Symposium 3:67-72.

Gerlach, J. D., JR. 1997b. The introduction, dynamics of geographic range expansion, and ecosystem effects of yellow starthistle (Centaurea solstitialis). Proceedings of the California Weed Science Society 49:136-141.

Giusti, G. A., R. B. Standiford, D. D. McCreary, A. Merenlender, and T. Scott. 2004. Oak woodland conservation in California's changing landscape. Berkeley, CA, USA: University of California Integrated Hardwood Range Management Program. $6 p$.

Gutierrez, A. P., M. J. Pitcairn, C. K. Ellis, N. Carruthers, and R. Ghezelbash. 2005. Evaluating biological control of yellow starthistle (Centaurea solstitialis) in California: a GIS based supply-demand demographic model. Biological Control $34: 115-131$

Hastings, A. 1996. Models of spatial spread: a synthesis. Biological Conservation 78:143-148

Hershdorfer, M. E., M. E. Fernandez-Gimenez, and L. D. Howery. 2007. Key attributes influence the performance of local weed management programs in the southwest United States. Rangeland Ecology \& Management 60:255-234.

Higins, S. I., D. M. Richardson, and R. M. Cowling. 2000. Using a dynamic landscape model for planning the management of alien plant invasions. Ecological Applications 10:1833-1848.

HOCHBERG, Y. 1988. A sharper Bonferroni procedure for multiple tests of significance. Biometrika 75:800-802.

Huntsinger, L., J. W. Bartolome, And C. M. D'Antonio. 2007. Grazing management of California grasslands. In: J. Corbin, M. Stromberg, and C. M. D’Antonio [EDS.]. Ecology and management of California grasslands. Berkeley, CA, USA: University of California Press. $400 \mathrm{p}$.

KaufMAn, M. M. 2000. Erosion control at construction sites: the science-policy gap. Environmental Management 26:89-97.

Kreuter, U. P., H. E. Amestoy, D. N. Ueckert, and W. A. McGinty. 2001. Adoption of brush busters: results of Texas county extension survey. Journal of Range Management 54:630-639.

Kreuter, U. P., M. R. Tays, and J. R. Conner. 2004. Landowner willingness to participate in a Texas brush reduction program. Journal of Range Management 57:230-237.

LeE, K. N. 1999. Appraising adaptive management. Conservation Ecology 3:3.

Liffmann, R. H., L. Huntsinger, and L. C. Forero. 2000. To ranch or not to ranch: home on the urban range? Journal of Range Management 53:362-370.

Ludwig, D., M. Mangel, and B. Haddad. 2001. Ecology, conservation, and public policy. Annual Review of Ecology and Systematics 32:481-517.

Maddox, D. M., and A. Mayfield. 1985. Yellow starthistle infestations on the increase. California Agriculture 39:10-12.

Moller, H., F. Berkes, P. O. B. Lyver, and M. Kislalioglu. 2004. Combining science and traditional ecological knowledge: monitoring populations for comanagement. Ecology and Society 9:2.

Morghan, K. J. R., And K. J. Rice. 2005. Centaurea solstitialis invasion success is influenced by Nassella pulchra size. Restoration Ecology 13:524-528.

Myers, N., R. A. Mittermeier, C. G. Mittermeier, G. A. B. Da Fonseca, and J. Kent. 2000. Biodiversity hotspots for conservation priorities. Nature 403:853-858.

Pitcairn, M. J., S. Schoenig, R. Yacoub, and J. Gendron. 2006. Yellow starthistle continues its spread in California. California Agriculture 60:83-90. 
Rejmánek, M., and M. J. Pitcairn. 2002. When is eradication of exotic pest plants a realistic goal? In: C. R. Veitch and M. N. Clout [EDS.]. Turning the tide: the eradication of invasive species. Gland, Switzerland: International Union for Conservation of Nature-Species Survival Commission Invasive Species Specialist Group. p. 249-253.

Rowan, R. C., H. W. Laedig, and L. D. White. 1994. Perceptions vs. recommendations: a rangeland decision making dilemma. Journal of Range Management 47:344-348.

Rowan, R. C., AND L. D. White. 1994. Regional differences among Texas rangeland operators. Journal of Range Management 47:338-343.

SHELEY, R. L. 1995. Integrated rangeland weed management. Rangelands 17:222-223.

Simon, H. A. 1959. Theories of decision-making in economics and behavioral science. The American Economic Review 49:253-283.

SMETHURST, D. 1999. Land degradation and the decline of ranching in the Sierra Nevada foothills, California. Land Degradation \& Development 10:161-175.

Smith, H. A., W. S. Johnson, J. S. Shonkwiler, and S. R. Swanson. 1999. The implications of variable or constant expansion rates in invasive weed infestations. Weed Science 47:62-66.

Standiford, R. B., J. Klein, and B. Garrison. 1996a. Sustainability of Sierra Nevada hardwood rangelands-Sierra Nevada Ecosystem Project: final report to Congress, volume III: assessments and scientific basis for management options. Davis, CA, USA: University of California, Centers for Water and Wildland Resources. p. 1-41.

Standiford, R. B., J. Klein, and B. Garrison. 1996b. Sustainability of Sierra Nevada hardwood rangelands. Davis, CA, USA: University of California, Centers for Water and Wildland Resources, University of California, Davis. $41 \mathrm{p}$.
Sun, M. 1997. Population genetic structure of yellow starthistle (Centauria solstitialis), a colonizing weed in the western United States. Canadian Journal of Botany 75:1470-1478.

TAYLOR, C. M., AND A. HAstings. 2004. Finding optimal control strategies for invasive species: a density-structured model for Spartina alterniflora. Journal of Applied Ecology 41:1049-1057.

Toman, E., B. Shindler, and M. Brunson. 2006. Fire and fuel management communication strategies: citizen evaluations of agency outreach programs. Society and Natural Resources 19:321-336.

US Census Bureau. 2002. United States Census. Available at: http://www.census. gov. Accessed on 16 April 2008.

[USDA-NASS] US Department of Agriculture-National Agricultural Statistics Service. 2002. Census of agriculture. Available at: http://www.agcensus. usda.gov. Accessed on 16 April 2008.

[USDA-NASS] US Department of Agriculture-National Agricultural Statistics Service. 2005. County agricultural commissioners' data. Available at: http:// www.nass.usda.gov. Accessed on 16 April 2008.

VON WIREN-LehR, S. 2001. Sustainability in agriculture-an evaluation of principal goal-oriented concepts to close the gap between theory and practice. Agriculture Ecosystems \& Environment 84:115-129.

Walker, P., and L. Fortmann. 2003. Whose landscape? a political ecology of the "exurban" Sierra. Cultural Geographies 10:469-491.

Zavaleta, E. S., and K. B. Hulvey. 2004. Realistic species losses disproportionately reduce grassland resistance to biological invaders. Science (Washington, $D C$ ) 306:1175-1177. 